\title{
Generic and specific volumetric equations for individual trees in the Tapajos National Forest, Eastern Amazon
}

\author{
Misael Freitas dos Santos ${ }^{1 *} \oplus$, João Ricardo Vasconcellos Gama²®, Daniele Lima da Costa ${ }^{1} \odot$,

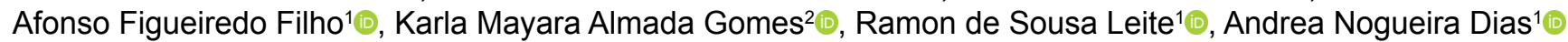

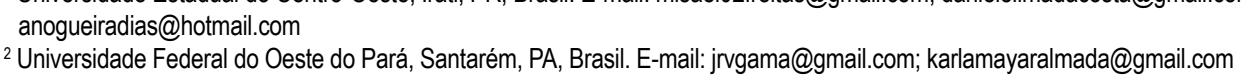

ABSTRACT: The objective of this study was to evaluate the use of volumetric models, through the application of identity tests, in seven Annual Production Units (APUs) of the Tapajos National Forest (TNF), as well as to verify the precision of equations adjusted by APU volume data from the previous year for use in the following year. A total sample size of 2100 stems were used for the adjustment of six models, and then the selected model was adjusted for the APU stratified data. The identity test, which compares adjusted equations using different datasets to verify whether or not a single equation could be used for all cases, was used to compare equations on various combinations of APUs, and a t-test was employed for validation of equations adjusted by APU data from the previous year. The identity test was significant for most comparisons, including the combinations of all the APUs, indicating that the use of one generic equation is not recommended for the entire management area. The t-test showed that there was a difference, for the majority of cases, between the observed and estimated volumes using the equation adjusted for the previous APU data. Therefore, the use of one general equation as well as equations adjusted based on data from APUs managed in the previous year is not recommended for volume estimation in TNF.

\section{Equações volumétricas genéricas e específicas para árvores individuais na Floresta Nacional do Tapajós, Amazônia Oriental}

RESUMO: O objetivo deste estudo foi avaliar, por meio do teste de identidade, o uso de modelos volumétricos em sete Unidades de Produção Anual (UPAs) na Floresta Nacional do Tapajós (FNT), assim como verificar a validade de equações ajustadas com dados de cubagem da UPA do ano anterior para utilização na UPA subsequente. Utilizou-se uma amostra total de 2.100 árvores (300 árvores por UPA) para o ajuste de seis modelos e, em seguida, o modelo selecionado foi ajustado para os dados estratificados por UPA. O teste de identidade, que compara equações ajustadas a partir de diferentes conjuntos de dados para verificar se uma única equação pode ser empregada para todos os casos, foi usado para comparar equações em várias combinações das UPAs, bem como o teste t para validação de equações ajustadas com dados da UPA do ano anterior. $O$ teste de identidade foi significativo para a maioria dos casos testados, incluindo a combinação de todas as UPAs, indicando que não é recomendável empregar-se uma equação genérica para toda a área de manejo. Para a maioria dos casos avaliados, o teste t indicou haver diferença entre o volume observado e o volume estimado com a equação ajustada com dados da UPA do ano anterior. Portando, o uso de uma equação genérica e de equações ajustadas com base nos dados das UPAs manejadas no ano anterior não é recomendado para a estimativa de volume na FNT.

Palavras-chave: espécies amazônicas; validação de equações; identidade de modelos; manejo madeireiro; modelagem volumétrica

\footnotetext{
* Misael Freitas dos Santos - E-mail: misael02freitas@gmail.com (Corresponding author)

Associate Editor: Rinaldo Luiz Caraciolo Ferreira
} 


\section{Introduction}

Forest management has as objective the use of existing resources to guarantee the renovation of the forest through reduction of harvest impacts on the remaining forest (Hosokawa et al., 2013). Several steps of forest management require precise estimates of commercial volume of standing trees since such estimates help forest managers to make a correct evaluation of the available timber stock and the production potential of the forests, as well as helping in the planning for wood harvest (Gama et al., 2017).

For this reason, volumetric equations are used in the Brazilian Amazon for estimation of commercial volume (volume of the commercial trunk to the height of the first bifurcation) of standing trees, and these equations should adjusted for the specific forest area that is being managed (Brasil, 2009). Various equations have been used in the Amazon region due to the large diversity of regional characteristics that can influence the variability of the stock of timber, such as the equation adjusted by Silva et al. (1984) for the Tapajos National Forest (TNF). However, when using this equation in specific locations in the TNF large errors in the estimates have been noticed (Gomes et al., 2018), thus requiring the development of equations that are made for specific locations which is seen as being the most efficient, economical, and precise method for the quantification of forest wood volume (Barros \& Silva Junior, 2009).

In areas under forest management in the Amazon the use of a generic equation is common for the estimation of commercial volume. On the other hand, certain companies, such as the Mixed Cooperative of the Tapajos National Forest (Coomflona) adjust specific equations for each Annual Production Unit (APU) due to APU structural variability. However, these equations are adjusted using data collected in APUs that were managed in previous years with the APUs not always being adjacent.

This procedure had the goal of dealing with the problem of a lack of data for the adjustment of the specific equation used for the APU that would be managed at a future date. Therefore, it was important to evaluate the performance of the equations that were generically employed to different locations in order to verify possible interference of variability between datasets on the performance of the equations and consequently on the precision of the estimates.

In this context, model identity is one of the options for the comparison of equations developed at different sites and is a tool that allows for determination of whether the sources in variation in forest structure significantly influence the volume estimation equations (Mendonça et al., 2015). Using this technique an assessment can be made to see if a single equation that groups data from distinct situations can be used, thus facilitating the estimation of timber production (Regazzi \& Silva, 2004, 2010). The model identity test is widely used in the forestry sector. For example, this test was used by Rufini et al. (2010), Vendruscolo et al. (2014), Mendonça et al. (2015) and Rodrigues et al. (2017) to compare volumetric models.
Statistical validation through comparison of mean observed and estimated volumes is also an alternative for the assessment of equations that come from distinct sites. According to Gimenez (2013), despite the great importance of volumetric equations there are several errors associated with their indiscriminate use, especially when an equation adjusted for a specific site is used at another site with distinct characteristics. This author emphasized that, besides the variation in stem form for each species, the site itself could be contribute to this variation. Validation was therefore one of the methods used in the current study to verify whether an equation developed in a specific APU could be used in another APU.

In this context, the objective of this study was to evaluate the use of volumetric models, through the application of identity tests in different Annual Production Units (APUs) of the Tapajos National Forest (TNF) in the Brazilian Amazon, including evaluations specifically for the three most important commercial species. This study also had the goal of verifying the precision of equations adjusted by APU volume data from the previous year for use in the following year.

\section{Materials and Methods}

\section{Study area}

This study was conducted in the Tapajos National Forest (TNF), a Federal Conservation Unit (CU) located in the west of the State of Pará (Figure 1) on the margin of the SantarémCuiabá highway (BR-163), located in the municipalities of Belterra, Aveiro, Placas and Rurópolis, between the geographic coordinates 2045 to $4010^{\prime} \mathrm{S}$ and $54045^{\prime}$ to 55o $30^{\prime} \mathrm{W}$. The CU occupies an area of approximately 544,927 hectares, and the topography varies from suavely undulating to undulating, with soils predominantly represented by yellow dystrophic Oxisols, and vegetation characterized by dense ombrophilous forest (Ibama, 2004). Rainfall is concentrated between January and May, with average annual precipitation of 1,820 $\mathrm{mm}$, and climate is classified as Ami in the Köppen system (hot and humid), with an average annual temperature of 25.5 ㅇ (Alvares et al., 2013).

\section{Data acquisition}

Data were obtained from forest inventories and rigorous volumetric measurements of boles with a $\mathrm{DBH}$ (diameter at breast height, measured at $1.3 \mathrm{~m}$ above the soil) $\geq 50 \mathrm{~cm}$, selected for harvest in seven APUs in the forest management area of the TNF. The volumetric analysis was done on the log landing area after sectioning the bole into 4 to 7-meter logs and removing the defective parts, and the volume of the individual logs was calculated using the Smalian method. The commercial volume (vc) of the stem was therefore the sum of the volumes of the individual logs.

The APUs are located in different areas along the SantarémCuiabá highway (BR-163): APUs 05 and 06 (km 83), APU 07 (km 72), APUs 08 and 09 (km 67) and APUs 10 and 11 (km 117) (Figure 1). Data were obtained from Coomflona, which has a 


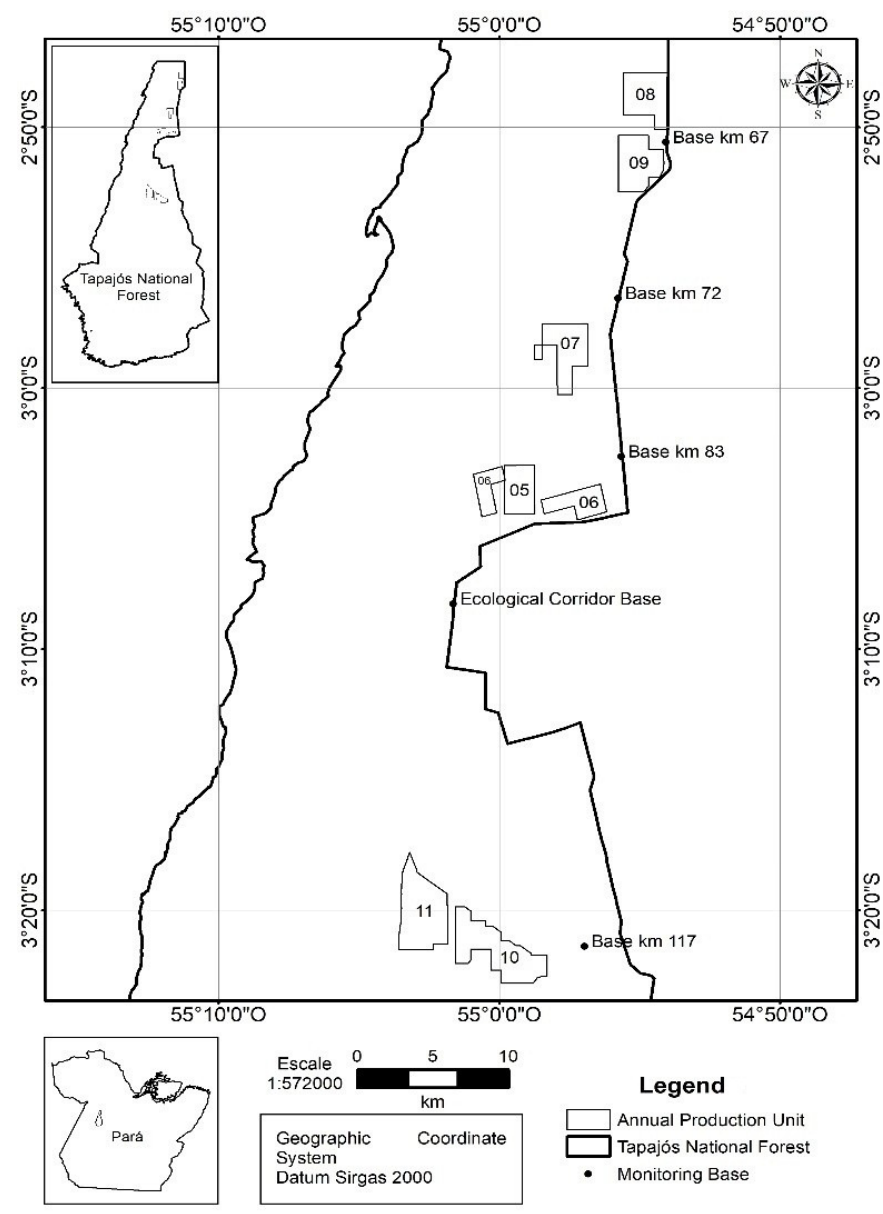

Figure 1. Location of the Tapajós National Forest and the Annual Production Units (APUs) along the Santarém-Cuiabá highway (BR-163), Pará, Brazil.

legal concession from the Brazilian government to conduct community forest management in an area of approximately 32,000 hectares in the TNF.

For each APU, 450 sample trees were selected among 41 commercial species, distributed in different DBH classes $(50 \mathrm{~cm}$ $\leq \mathrm{DBH}<170 \mathrm{~cm}$ ), of which 300 were used for the adjustment of the volumetric models (2,100 trees total in seven APUs). The other 150 (from a total of 1,050 sample trees for the seven APUs) were used for the process of equation validation, which is described below. The selection was done using the number of trees in each DBH class.

The sample size was based on the variability of the commercial volume, for the adjustment as well as the validation. The number of sample trees ( $n$ ) needed to represent the population of each APU, for each dataset (adjustment and validation), was calculated using Equation 1, considering the population to be finite (Soares \& Paula-Neto, 1997):

$$
\mathrm{n}=\frac{\mathrm{t}^{2} \mathrm{CV}^{2}}{(\mathrm{E} \%)^{2}+\frac{\mathrm{t}^{2} \mathrm{CV}^{2}}{\mathrm{~N}}}
$$

where $\mathrm{n}$ - number of sample trees needed; $\mathrm{t}$ - $\mathrm{t}$-value associated with a $5 \%$ probability level and $n-1$ degrees of freedom; CV variation coefficient of the commercial volume; $\mathrm{E} \%$ - required precision (10\%); $\mathrm{N}=$ total number of trees in the population.

In this way, it was demonstrated that $\mathrm{n}=300$ was statistically representative of the population for volumetric model adjustment by APU so that sampling error was below $10 \%$ for all the APUs (Table 1). Additionally, the value $n=150$ was shown to be sufficient to represent the population of the APUs in the model validation process, with exception of APU 08, which needed 19 additional sample trees to attain a sampling error under $10 \%$ (Table 1 ).

\section{Volumetric model adjustment}

Before adjustment of the volumetric models, the Pearson test was used to verify correlation between the volume and the explanatory variables $\mathrm{DBH}$ and hc. The significance of the correlation was tested using a F test ( $\alpha=0.01$ ).

Three single-entry models were tested with $\mathrm{DBH}$ as the input variable and three double-entry models with $\mathrm{DBH}$ and hc as input variables, which are among the principal models tested in most studies done in the Amazon (Cysneiros et al., 2017; Barreto et al., 2014; Gimenez et al., 2015; Rolim et al., 2006; Thaines et al., 2010; Tonini \& Borges, 2015) (Table 2).

The six models were initially adjusted for each sample tree for each APU, thus obtaining a general equation. Subsequently, the model selected for these data was adjusted for stratified data for each APU to obtain specific equations.

In order to verify the occurrence of outliers in the dataset, residual standardization was conducted, as recommended by Scolforo (2005). After an initial adjustment of each model based on all the sampled trees, a ratio of estimated residuals and standard error of the estimate $\left(e_{i} / S_{y x}\right)$ was obtained. According to this author, when sample size is $n \geq 120$, about

Table 1. Samples used for adjustment and validation of the volumetric models by Annual Production Unit (APU).

\begin{tabular}{cccccccc}
\hline \multirow{2}{*}{ APU } & \multirow{2}{*}{$\mathbf{N}$} & \multicolumn{3}{c}{ Adjustment } & \multicolumn{3}{c}{ Validation } \\
\cline { 3 - 7 } & & n needed & n selected & E (\%) & n needed & n selected & E (\%) \\
\hline 05 & 1,986 & 121 & 300 & 6.05 & 130 & 150 & 9.27 \\
06 & 2,144 & 117 & 300 & 5.94 & 146 & 150 & 9.85 \\
07 & 2,600 & 137 & 300 & 6.53 & 132 & 150 & 9.33 \\
08 & 2,920 & 123 & 300 & 6.21 & 141 & 169 & 9.86 \\
09 & 4,974 & 144 & 300 & 6.82 & 122 & 150 & 9.68 \\
10 & 4,671 & 154 & 300 & 7.05 & 128 & 150 & 9.00 \\
11 & 4,454 & 155 & 300 & 7.06 & 9.22 \\
\hline
\end{tabular}

APU = Annual Production Unit; $N=$ total number of trees in the population of each APU; $n$ needed = number of sample trees statistically necessary for each APU for model adjustment and validation; $n$ selected $=$ number of sample trees randomly selected by APU UPA for model adjustment and validation; $E$ (\%) sampling error. 
Table 2. Volumetric models tested for seven Annual Production Units (APU) in the management area of the Tapajós National Forest, Pará, Brazil.

\begin{tabular}{cccc}
\hline Number & Author & Statistical Model & Entry variables \\
\hline 1 & Berkhout & $v=\beta_{0}+\beta_{1} D B H+\varepsilon_{i}$ & Single (DBH) \\
2 & Husch & $\ln v=\beta_{0}+\beta_{1} \ln D B H+\varepsilon_{i}$ & \\
3 & Brenac & $\ln v=\beta_{0}+\beta_{1} \ln D B H+\beta_{2} 1 / D B H+\varepsilon_{i}$ & Double (DBH and hc) \\
4 & Spurr (logarithmic) & $\ln v=\beta_{0}+\beta_{1} \ln \left(D B H^{2} h c\right)+\varepsilon_{i}$ & \\
5 & Schumacher-Hall & $\ln v=\beta_{0}+\beta_{1} \ln D B H+\beta_{2} \ln h c+\varepsilon_{i}$ & \\
\hline
\end{tabular}

$\mathrm{v}$ - commercial volume with bark, in $\mathrm{m}^{3}$; BBH - diameter at $1.3 \mathrm{~m}$, in cm; hc - commercial height ( $\left.\mathrm{m}\right) ; \beta_{0}, \beta_{1}, \beta_{2}$ and $\beta_{3}$ - regression coefficients to be estimated; In - neperian logarithm; and $\varepsilon_{\mathrm{i}}$ - random error.

$95 \%$ of the values of this ratio are between -1.96 and +1.96 . The remainder of the values can be considered to be outliers and are therefore removed from the dataset. After this procedure the six models were readjusted, and the one with the best performance was chosen.

The selection of the best volumetric model was done based on statistical criteria that indicated the quality of the model adjustment with a larger coefficient of determination, which was corrected using the Schlaegel Index to allow for comparison of models with different dependent variables (Equation 2), a lower value of the standard error for the estimate (Equation 3), and homogeneous distribution and independence of the residuals (Equation 4) (Machado et al., 2008; Campos \& Leite, 2017):

$$
\begin{gathered}
\mathrm{R}_{\mathrm{adj}}^{2}=1-\left(1-\mathrm{R}^{2}\right)\left(\frac{\mathrm{n}-1}{\mathrm{n}-\mathrm{k}}\right) \\
\mathrm{S}_{\mathrm{yx}} \%=\frac{\left(\frac{\sqrt{\sum_{\mathrm{i}=1}^{\mathrm{n}}(\mathrm{y}-\hat{\mathrm{y}})^{2}}}{\mathrm{n}-\mathrm{k}}\right)}{\overline{\mathrm{y}}} 100 \\
\operatorname{Res}(\%)=\frac{(\hat{\mathrm{y}}-\mathrm{y})}{\mathrm{y}} 100
\end{gathered}
$$

where $R^{2}{ }_{a j}$ - adjusted coefficient of determination; $R^{2}$ coefficient of determination; $\mathrm{n}$ - number of observations (sample trees $-i=1,2,3, \ldots, n$ ); $k$ - number of model coefficients; $\mathrm{S}_{\mathrm{yx}} \%$ - standard error of the estimate, as a percentage; $y$-observed commercial volume of the $i^{\text {th }}$ tree, in $\mathrm{m}^{3} ; \mathrm{y}$ - estimated commercial volume of the $\mathrm{i}^{\text {th }}$ tree, in $\mathrm{m}^{3}$; $y$ - average of the observed commercial volume of the sample trees, in $\mathrm{m}^{3}$; Res (\%) - percent residuals.

For the logarithmic models, the $\mathrm{R}^{2}$ aj was recalculated for the variable of interest to compare different types of equations. The logarithmic models $2,3,4$ and 5 had their $\mathrm{S}_{\mathrm{yx}} \%$ recalculated because the values obtained from the analysis of variance of the regression were in a logarithmic scale.

The coefficients of the models were estimated by the ordinary least squares method, and significance was tested using a t-test $(\alpha=0.05)$. In order to evaluate multicollinearity effects between the independent variables of the double- entry models, a Variance Inflation Factor (VIF) test was applied, and VIF values less than 10 indicated the absence of multicollinearity (Gujarati \& Porter, 2011).

\section{Identity test}

The model identity test proposed by Graybill (1976) and demonstrated by Regazzi (1993) was used for the comparison of different equations for the APUs. This test consists of a reduction in the sum of squares, which allows for statistical verification through an $F$ test of the significance of the difference between the total sums of squares of the adjusted regressions for each individual APU (complete model), and the sum of the square of the regression adjusted for the entire dataset (reduced model). The null hypothesis tested was $\mathrm{H}_{0}$ : $\beta_{0}=\beta_{1}=\ldots=\beta_{n}$. Acceptance of $H_{0}$ led to the conclusion (for $F_{c a l}$ $<F_{\text {tab }[(U-1) p ; N-U p]}$ ' at a significance level of $\alpha=0.05$ ) that the ' $n$ ' equations are not statistically different amongst themselves, assuming that a single equation can represent the entire dataset.

Besides the combination of all the APUs of the managed area (combination 1), eight additional combinations between the APUs were done to apply the identity test (Table 3 ). Six of them (combinations 2, 3, 4, 5, 6 and 7) were done in order to check for the possibility of an equation developed with data from the volume of the APU from the previous year to be used in the volume estimates for the subsequent year. It was hypothesized that if the equations for the APUs for both years were statistically equal, this process would be adequate. Combinations 5 and 7 were conducted as a function of spatial grouping of the UPAs at different locations along the SantarémCuiabá highway (BR-163), as well as for combinations 8 and 9. This procedure tested the possibility that a single equation can represent the APUs from each site, namely: APUs 05, 06 and 07 ( $\mathrm{km} 83$ and 72); APUs 08 and 09 ( $\mathrm{km} \mathrm{67);} \mathrm{APUs} \mathrm{07,} 08$ and 09 ( $\mathrm{km} 72$ and 67) and APUs 10 and 11 ( $\mathrm{km} \mathrm{117).} \mathrm{APU} 07$ was combined separately with APUs 05 and 06 , as well as with UPAs 08 and 09 since it is at an intermediate distance between these APUs (Figure 1).

\section{Validation of the equations developed with APU data from} the previous year

The validation shows how an equation, adjusted for a specific group of data, behaves when used to estimate data that are independent of those used in the adjustment. In the current study this method was used with the goal of verifying 
Table 3. Combinations of annual production units (APUs) for the application of the model identity test.

\begin{tabular}{ccc}
\hline Combinations & APUs & Situations \\
\hline 1 & $05,06,07,08,09,10$ and 11 & All APUs representing the managed area \\
2 & 05 and 06 & Equation adjusted with data from APU 05 and used in APU 06 \\
3 & 06 and 07 & Equation adjusted with data from APU 06 and used in APU 07 \\
4 & 07 and 08 & Equation adjusted with data from APU 07 and used in APU 08 \\
5 & 08 and 09 & Equation adjusted with data from APU 08 and used in APU $08 ;$ APUs located at km 67 \\
6 & 09 and 10 & Equation adjusted with data from APU 09 and used in APU 10 \\
7 & 10 and 11 & Equation adjusted with data from APU 10 and used in APU $11 ;$ APUs located at km 117 \\
\hline 8 & 05,06 and 07 & APUs located at Km 83 and 72 \\
\hline
\end{tabular}

the possibility that an equation adjusted using data from one APU can be applied to an APU during the following year.

The commercial volume of the sample trees separated for the validation process was estimated using the equation developed from volume data for the APU from the previous year, for six cases: Case 1 (equation from APU 05 used in APU 06); Case 2 (equation from APU 06 used in APU 07); Case 3 (equation from APU 07 used in APU 08); Case 4 (equation from APU 08 used in APU 09); Case 5 (equation from APU 09 used in APU 10), and Case 6 (equation from APU 10 used in APU 11). Subsequently, a t-test $(\alpha=0.05)$ was employed to verify the validity of the estimates in relation to the observed volume. The null hypothesis tested was $\mathrm{H}_{0}: \mathrm{v}_{\text {(observed) }}=\mathrm{v}_{\text {(estimated) }}$ and was accepted when $\mathrm{t}_{\text {calc }}<\mathrm{t}_{\text {tab }(\alpha=0.05)}$.

Each case was also evaluated using the average error of the volumetric estimate in absolute (Equation 5) and relative (Equation 6) terms, which compares the observed volume with the volume estimates made using the equations thus allowing for the estimation of the degree of error that could be committed if the adjusted equations for the managed APUs from previous years were used.

$$
\begin{gathered}
\operatorname{AAE}\left(\mathrm{m}^{3}\right)=\frac{\frac{\left(\hat{\mathrm{v}}_{\mathrm{i}}-\mathrm{v}_{\mathrm{i}}\right)}{\mathrm{v}_{\mathrm{i}}}}{\mathrm{n}} \\
\operatorname{ARE}(\%)=\operatorname{AEA}\left(\mathrm{m}^{3}\right) 100
\end{gathered}
$$

where $\operatorname{AAE}\left(\mathrm{m}^{3}\right)$ - average absolute error, in $\mathrm{m}^{3}$; ARE (\%) average relative error; $v_{i}$ - observed commercial volume of the $\mathrm{i}^{\text {th }}$ tree, in $\mathrm{m}^{3} ; \mathrm{v}_{\mathrm{i}}$ - estimated commercial volume of the $\mathrm{i}^{\mathrm{th}}$ tree, in $\mathrm{m}^{3} ; \mathrm{n}$ - number of sample trees.

\section{Analysis by species}

In a complementary analysis, data from the three most important commercial species, namely: Lecythis sp. (Jarana), Manilkara sp. (Maçaranduba) and Couratari sp. (Tauari), that together represented $45.5 \%$ of the total number of trees harvested in the seven APUs, were stratified (Table 4) and then the model selected in the initial analysis (considering all species) was adjusted in separate for each one of these species. In order to apply the identity test, the model was initially adjusted taking into consideration the data from all the APUs (reduced model) and subsequently using stratified data for each APU, and seven equations were generated (complete model) for each species. The combinations presented in Table 3 were then tested for each species. In this analysis, all the sample trees for the three species from each APU were used, in contrast to the analysis that used all species, where the sample trees were randomly selected by APU.

Validation of the adjusted equations based on volume of the APU managed the previous year was done for each species with respect to the following six possible cases: Case 1 (equation from APU 05 used in APU 06); Case 2 (equation from APU 06 used in APU 07); Case 3 (equation from APU 07 used in APU 08); Case 4 (equation from APU 08 used in APU 09); Case 5 (equation from APU 09 used in APU 10), and Case 6 (equation from APU 10 used in APU 11). A database was setup for each APU (Table 4), and not used for equation adjustment, but instead were used for comparison of observed and estimated volumes using a t-test at $\alpha=0.05$ ).

Table 4. Number of sample trees used in the adjusts (AJ) and validation of the equations (V), for the three species with the greatest number of harvested trees in the seven Annual Production Units (APUs), in the Tapajós National Forest management

\begin{tabular}{|c|c|c|c|c|c|c|}
\hline \multirow{2}{*}{ APU } & \multicolumn{2}{|c|}{ Lecythis sp. } & \multicolumn{2}{|c|}{ Manilkara sp. } & \multicolumn{2}{|c|}{ Couratari sp. } \\
\hline & AJ & V & AJ & V & AJ & V \\
\hline 5 & 184 & 50 & 302 & 75 & 288 & 65 \\
\hline 6 & 198 & 50 & 484 & 75 & 310 & 65 \\
\hline 7 & 371 & 50 & 437 & 75 & 200 & 65 \\
\hline 8 & 338 & 50 & 67 & 75 & 334 & 65 \\
\hline 9 & 574 & 50 & 591 & 75 & 423 & 65 \\
\hline Totals & 2007 & 350 & 4714 & 525 & 2102 & 455 \\
\hline
\end{tabular}
area. 


\section{Results and Discussion}

\section{Sample volume and correlation}

The observed volume for the 2,100 sample trees used in the adjustments was $18,705.04 \mathrm{~m}^{3}$ with an average of $8.91 \mathrm{~m}^{3}$ per tree, and a coefficient of variation of $61.7 \%$, representing an average of 24 commercial species. The average $\mathrm{DBH}$ of these trees was $92.2 \mathrm{~cm}(\mathrm{CV}=25.3 \%)$ and the average hc was $21.6 \mathrm{~m}$ ( $\mathrm{CV}=24.0 \%$ ). The Pearson correlation coefficient observed between volume and $\mathrm{DBH}$ was high and significant $(\alpha \leq 0.01)$ in all the APUs UPAs, varying from 0.788 to 0.872 . The correlation between volume and commercial height (hc) varied from 0.474 to 0.609 between the APUs and was statistically significant by the F-test. The correlation between the variables indicated that volume can be adequately explained by the input variables. Specifically, for the set of trees used in the validation (1,050 trees), the total volume was $10,679.48 \mathrm{~m}^{3}$, with an average of $10.2 \mathrm{~m}^{3}$ (CV = 73.8\%), with average $\mathrm{DBH}$ of $89.0 \mathrm{~cm}(\mathrm{CV}=27.1 \%)$ and average hc of $19.2 \mathrm{~m}(\mathrm{CV}=36.0 \%)$.

\section{Equation selection for the entire sample}

The six tested volumetric models were adjusted for the entire sample of 2,100 trees independent of APU. Table 5 shows the estimated coefficients and the statistical adjustments and equation precision obtained after residual standardization.

In general, the double-entry models had superior performance when compared to the single-entry models, thus showing the importance of the inclusion of the height variable in the models, in spite of the fact that height is difficult to measure, especially in tropical forests (Cysneiros et al., 2017).

For the double-entry models, the logarithmic Spurr and the Schumacher-Hall equations presented significant coefficients by the t-test ( $p \leq 0.05$ ) and similar statistics, as well as homogeneous distribution of residuals (Figures $2 \mathrm{~A}$ and 2B). Nevertheless, after standardization of the residuals, the Schumacher-Hall model was selected to represent the entire dataset and used in the next step of this study.

It is observed in Figure 2B that, in spite of errors indicating overestimation of volumes for both models, the equation adjusted using the Schumacher-Hall model minimized this tendency, even if only minimally. This equation did not show multicollinearity, with a Variance Inflation Factor of 1.058 for both independent variables. The Stoate model, despite generating an error slightly lower than the other models, presented multicollinearity, with VIF values larger than 10 for two of the three independent variables.

The selection of the Schumacher-Hall model was also made as a function of its better performance in other studies done in the Amazon (Cysneiros et al., 2017; Colpini et al., 2009; Rolim et al., 2006; Tonini \& Borges, 2015), including in the TNF, where Ribeiro et al. (2014) showed that this model was adequate for commercial volume estimates. Previously, Silva et al. (1984) also reported in their studies in the TNF that, among the double-entry models, the Schumacher-Hall model as the best fitted. Furthermore, this model is among those selected and used by Coomflona for their estimates of volume.

Table 5. Coefficients and statistics of the adjusted equations for estimation of commercial volume (including bark) using data for all the Annual Production Units in the managed area of the Tapajós National Forest.

\begin{tabular}{|c|c|c|c|c|c|c|}
\hline \multirow{2}{*}{ Models } & \multicolumn{4}{|c|}{ Regression coefficients } & \multirow{2}{*}{$\mathbf{R}^{2}{ }_{a j}$} & \multirow{2}{*}{$\mathrm{S}_{\mathrm{yx}} \%$} \\
\hline & $\beta_{0}$ & $\beta_{1}$ & $\beta_{2}$ & $\beta_{3}$ & & \\
\hline Berkhout & $-8.56403^{*}$ & $0.18772 *$ & & & 0.78 & 26.35 \\
\hline Husch & $-7.24459 *$ & $2.05850^{*}$ & & & 0.79 & 25.98 \\
\hline Brenac & $-5.67739 *$ & $1.77126^{*}$ & $-24.13001^{n s}$ & & 0.78 & 26.01 \\
\hline Spurr (logarithmic) & $-8.82315^{*}$ & $0.90025^{*}$ & & & 0.89 & 19.19 \\
\hline Schumacher-Hall & $-8.80511^{*}$ & $1.78757^{*}$ & $0.91322^{*}$ & & 0.89 & 19.10 \\
\hline Stoate & $-0.01078^{n s}$ & $0.00012^{*}$ & $0.00003^{*}$ & $0.03579 *$ & 0.90 & 18.81 \\
\hline
\end{tabular}

$\mathrm{R}_{\text {aj }}^{2}$ - adjusted coefficient of determination; $S_{y x} \%$ - estimate standard error (\%); $\beta_{0}, \beta_{1}, \beta_{2}$ and $\beta_{3}$ - model coefficients; ${ }^{*}$ - significant by t-test ( $\left.p \leq 0.05\right) ;{ }^{\text {ns }}$ - not significant by t-test ( $\left.p \geq 0.05\right)$.

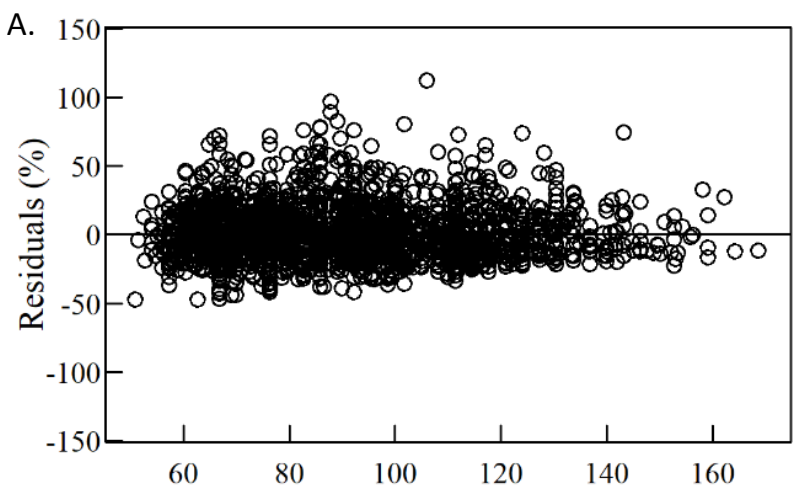

$\mathrm{DBH}(\mathrm{cm})$

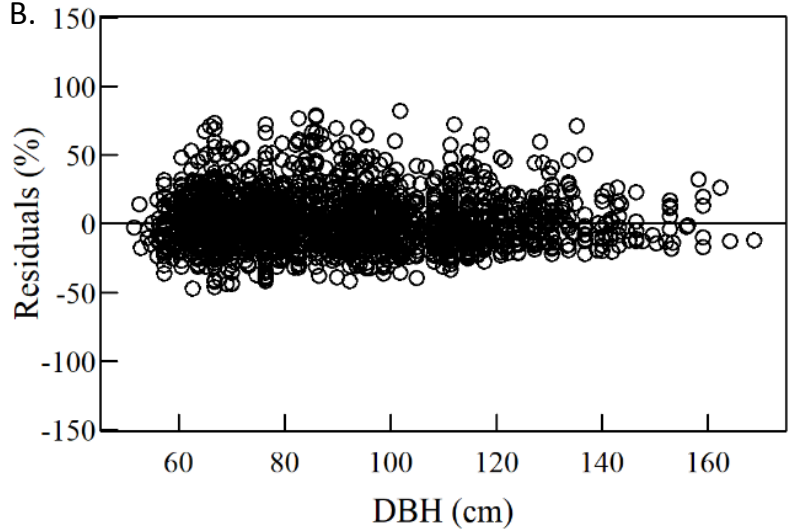

Figure 2. Residual distribution in relation to diameter (DBH) for the Spurr logarithmic (A) and Schumacher-Hall (B) adjusted models for the entire dataset. 
According to Campos \& Leite (2017), the Schumacher-Hall model is efficient due to its statistical properties since it usually generates results without tendency patterns. According to Andrade (2017), of the eight volumetric models most-used in Brazil during recent years, the Schumacher-Hall model was selected in $41 \%$ of the studies.

The Schumacher-Hall model was adjusted for each one of the seven APUs, and the coefficients estimated, as well as the fit and precision statistics are presented in Table 6 . Considering the heterogeneous characteristics of tropical forests, which generally make adjustment of results difficult, the equations obtained in this study present precision statistics that indicate good adjustment.

The $\mathrm{R}^{2}$ adj varied from 0.88 to 0.91 and the $\mathrm{S}_{\mathrm{yx}} \%$ from $17.26 \%$ to $20.12 \%$. In general, the stratification of data by APU resulted in a reduction in estimation errors for APUs 06, 07, 08, 09 and 11 , with respect to the general equation, thus indicating the necessity of an equation for each APU. There were no problems with multicollinearity (VIF < 10) among the independent variables for the Schumacher-Hall model adjusted by APU for all cases, as observed for the adjustment for the entire sample.

Table 6. Coefficients and statistics of adjusted equations for the Schumacher-Hall model to estimate commercial volume by Annual Production Unit in the managed area of the Tapajós National Forest.

\begin{tabular}{cccccc}
\hline \multirow{2}{*}{ APUs } & \multicolumn{3}{c}{ Regression coefficients } & \multirow{2}{*}{$\mathbf{R}^{\mathbf{2}}{ }_{\text {aj }}$} & \multirow{2}{*}{$\mathbf{S}_{\mathrm{yx}} \%$} \\
\cline { 2 - 4 } & $\boldsymbol{\beta}_{0}$ & $\boldsymbol{\beta}_{1}$ & $\boldsymbol{\beta}_{2}$ & & \\
\hline 05 & $-8.9873^{*}$ & $1.7978^{*}$ & $0.9371^{*}$ & 0.88 & 20.12 \\
06 & $-8.7496^{*}$ & $1.8628^{*}$ & $0.7846^{*}$ & 0.90 & 17.29 \\
07 & $-8.9331^{*}$ & $1.7892^{*}$ & $0.9593^{*}$ & 0.91 & 17.83 \\
08 & $-8.8076^{*}$ & $1.8122^{*}$ & $0.8728^{*}$ & 0.89 & 18.34 \\
09 & $-9.0531^{*}$ & $1.8745^{*}$ & $0.8525^{*}$ & 0.90 & 18.44 \\
10 & $-9.1718^{*}$ & $1.7917^{*}$ & $1.0184^{*}$ & 0.90 & 19.35 \\
11 & $-8.2871^{*}$ & $1.7443^{*}$ & $0.8494^{*}$ & 0.91 & 17.26 \\
\hline
\end{tabular}

$\mathrm{R}_{\mathrm{aj}}{ }^{-}$-adjusted coefficient of determination; $S_{y y} \%$ - estimate standard error (\%); $\beta_{0}, \beta_{1}, \beta_{2}$ coefficients; ${ }^{*}$ - significant by t-test $(p \leq 0.05)$.

\section{Identity test}

The results for the identity tests for the models are shown in Table 7. For the set of grouped data for all the evaluated APUs (combination 1 ), the result was significant $(\alpha \leq 0.05)$. A non-significant result meant that specific equations for each APU were not needed, but when the result was significant tests were continued for the other combinations.
For the combinations 2, 3, 7, 8 and 9, the test was also significant $\left(F_{\text {calc }}>F_{\text {tab }}\right)$, indicating that the use of a single adjusted equation for the entire set of data is not recommended in these cases. However, for combinations 4, 5 and 6, the equations developed separately for each APU were not statistically different, indicating that a general equation could be used for both APUs in these three cases, thus making the calculations less onerous and reducing sampling costs.

As indicated by the identity test, it is not adequate to use a single equation for the entire managed area in the TNF. Furthermore, most of the areas under commercial timber management in the Amazon are very extensive, which maximizes structural variation of the forest, thus making difficult the representation of the entire managed area by one general equation. Equations used in a generic manner for large areas such as that of the TNF (Silva et al., 1984) can cause large errors in the estimates as stated by Gomes et al. (2018), thus confirming the necessity to generate equations for specific areas.

Rufini et al. (2010) applied an identity test for volumetric equations in savannah (sensu stricto) in the State of Minas Gerais for three different regions in the São Francisco River basin. The authors reported that it was possible to use a single equation only for two of the sampled regions, with an individual adjust being done for the remaining region since it presented different characteristics than the other sites. Results such as these, as well as those from the present study, indicate that as variations in edaphic and climatic characteristics between sites can have direct effects on the adjusted equations because this can lead to variations in forest structure and consequently in relationships between dendrometric variables.

With respect to the TNF, the variation in characteristics such as soil and topography, is evident, especially in the north to south direction in which the APUs are spatially distributed. According to Espírito-Santo et al. (2005), there are also three distinct phytogeographic patterns in the TNF. As related by Soares et al. (2011), Valente et al. (2011) and Barreto et al. (2014), variable conditions of climate, soil and topography, as well as water availability, influence growth and the relationship between forest dendrometric variables.

Soil type is one of the principal factors that determines the structure of a forest (Loures et al., 2007; Souza et al., 2006),

Table 7. Analysis of variance for the Graybill identity test used in the comparison of equation adjustment for the nine tested combinations.

\begin{tabular}{|c|c|c|c|c|c|c|}
\hline Combination & APUs & MS (difference) & MS (residual) & $F_{\text {calc }}$ & $\mathrm{F}_{\mathrm{tab} 5 \%}$ & Test \\
\hline 1 & $05,06,07,08,09,10$ and 11 & 0.3991 & 0.0339 & 11.773 & 1.609 & $\mathrm{~s}$ \\
\hline 2 & 05 and 06 & 0.2422 & 0.0390 & 6.208 & 2.621 & s \\
\hline 3 & 06 and 07 & 0.1099 & 0.0313 & 3.509 & 2.621 & s \\
\hline 5 & 08 and 09 & 0.0427 & 0.0332 & 1.286 & 2.621 & ns \\
\hline 6 & 09 and 10 & 0.0693 & 0.0340 & 2.035 & 2621 & ns \\
\hline 9 & 07,08 and 09 & 0.1056 & 0.0322 & 3.279 & 2.109 & $\mathrm{~s}$ \\
\hline
\end{tabular}

MS - Mean Square; $F_{\text {calc }}$ - calculated F statistic; $F_{\text {tab }}$ - tabulated F statistic; $n s$ - not significant $(\alpha \leq 0.05)$, do not reject $H_{0}$; and s - significant $(\alpha \leq 0.05)$, reject $\mathrm{H}_{0}$. 
and therefore directly influences dendrometric relationships. The predominant soil in the TNF is a dystrophic yellow Oxisol (Ibama, 2004), although there is also a substantial presence of red-yellow Podzols (Hernandez Filho et al., 1993). However, studies done in specific areas of the TNF have identified localized variations in soil types.

According to Ibama (2004), the Foundation for Forest Research (FUPEF) conducted a study in 1986 near km 83 (BR163) of the managed area of the current study and related the soil type to the vegetation. The study found that, depending on the soil type, the forest can vary in vegetation density, and in some cases the less-dense forest can have a larger presence of vines with trees of smaller diameter (DBH $<55 \mathrm{~cm})$.

In this context, the development of equations that are specific to each site is recommended to minimize the effect of structural variability on the mathematical relations developed in the analysis, thus resulting in more precise estimates. With respect to the economic importance of forestry activities, Gama et al. (2017) related that the incorrect quantification of volumetric can lead to economic loss, and therefore incorrect inferences are unacceptable in terms of the sustainability of forestry operations.

Validation of the equations developed with APU data from the previous year

The difference between the observed and the estimated volumes from the equations developed from the volume input data of the APU from the previous year was significant $(p<0.05)$ for cases 1, 2, 5 and 6 using a t-test (Table 8), since the t-table for 149 degrees of freedom for the adopted significance level was 1.97. Except for case 5, for the remainder of the cases for which a significant difference was found, the results were compatible with those from the identity test, indicating that the use of data from the APU for the previous year for the development of an equation for use in the subsequent year is not adequate in these APUs.

For the majority of cases the average error for the volumetric estimation was large, mainly for cases 1 and 6, in which the equations tended to underestimate the commercial volumes (Table 8 ). The values indicate that the error is related to the decision to use equations adjusted using data from APUs managed in the previous years.

In contrast, the volumes estimated in APUs 08 and 09 using volume equations from APUs 07 and 08, respectively (cases 3 and 4), were not statistically different from the observed volumes ( $p>0.05$ ). This corroborates the result of statistical equality shown by the identity test for equations developed for both cases. These observations indicate that, in these specific cases, the use of equations developed from the previous year's volume data is an adequate procedure.

In a similar test, Gomes et al. (2018) also observed that the estimated volume in APU 08 using an equation adjusted by data for APU 07 was not statistically different from the observed volume through analysis using a Qui-square test at $95 \%$ probability $(p=0.4273)$. The authors concluded that it would be possible to use an equation adjusted using data from a harvest in the APU from the previous year to estimate the volume to be harvest in the following year.

From a statistical point of view, the use of a generic equation for most cases is not recommended, even though this would be more practical and economical for the company conducting the forestry operation. For a few specific cases, the statistical tests indicated the possibility of optimizing the volume calculations using generic equations or ones developed based on APU data from the previous year. This lack of uniformity in the results demonstrates that the elaboration of a generic equation is directly related to site characteristics, and therefore that studies should be conducted before decisions are made on management activities.

\section{Analysis by species}

The Schumacher-Hall model was selected for species analysis taking into consideration all species in a single dataset, and this model was also used for the adjusts and evaluations for the Lecythis sp., Manilkara sp. and Couratari sp. species separately.

The identity test done for each of the three species is presented in Table 9, and these results show statistical significance for the majority of tested cases, except for cases 3 and 5 for, case 4 for Manilkara sp. and case 7 for Couratari sp.

As indicated by the test for the entire group of commercial species together, it is not adequate to use a generic equation for the different APUs, even if these equations are separately adjusted for the three different species. This demonstrated the necessity of generating specific equations for each APU, as well as for the species Lecythis sp., Manilkara sp. and Couratari sp., so that more accurate estimates are obtained. Although this procedure is more costly for the forestry harvesting company, management is responsible for deciding if the gain in precision economically justifies the development of specific equations.

Table 8. T-test $(\alpha<0.05)$ applied for comparison of observed and estimated volumes using equations obtained from APU volume data from the previous year, and average error for the volumetric estimation.

\begin{tabular}{ccccc}
\hline Cases & $\mathbf{t}_{\text {calc }}$ & $p$-value & AAE $\left(\mathbf{m}^{3}\right)$ & ARE $(\%)$ \\
\hline 1 (Equation from APU 05 used for APU 06) & 4.566 & 0.0000 & -0.0771 & -7.71 \\
2 (Equation from APU 06 used for APU 07) & 2.420 & 0.0167 & -0.0050 & -0.50 \\
3 (Equation from APU 07 used for APU 08) & 0.517 & 0.6058 & 0.0422 & 4.22 \\
4 (Equation from APU 08 used for APU 09) & 0.801 & 0.4245 & 0.0236 & -0.0511 \\
5 (Equation from APU 09 used for APU 10) & 6.478 & 0.0000 & -0.1468 \\
6 (Equation from APU 10 used for APU 11) & 9.132 & 0.0000 & -14 \\
\hline
\end{tabular}

APU - Annual Production Unit; AAE $\left(\mathrm{m}^{3}\right)$ - average absolute error, in $\mathrm{m}^{3}$; ARE (\%) - average relative error; $\mathrm{t}_{\text {calc }}$ - calculated $\mathrm{t}$-statistic value; $p$-value - value of the statistical significance test. 
Table 9. Analysis of Variance for the Graybill identity test used for the comparison of adjustments for nine combinations and three of the most commercially important species in the management area of the Tapajós National Forest.

\begin{tabular}{|c|c|c|c|c|c|c|c|c|c|c|}
\hline \multirow[b]{2}{*}{ C } & \multirow{2}{*}{ APUs } & \multicolumn{3}{|c|}{ Lecythis sp. } & \multicolumn{3}{|c|}{ Manilkara sp. } & \multicolumn{3}{|c|}{ Couratari sp. } \\
\hline & & $\mathrm{QM}^{1}$ & $\mathrm{QM}^{2}$ & $F_{\text {calc }}$ & $\mathrm{QM}^{1}$ & $\mathrm{QM}^{2}$ & $F_{\text {calc }}$ & $\mathrm{QM}^{1}$ & $\mathrm{QM}^{2}$ & $F_{\text {calc }}$ \\
\hline 1 & $05,06,07,08,09,10$ and 11 & 0.3164 & 0.0215 & $14.72 *$ & 2.6715 & 0.0196 & $136.05^{*}$ & 0.3178 & 0.0419 & $7.59 *$ \\
\hline 2 & 05 and 06 & 0.8187 & 0.0219 & $37.45^{*}$ & 0.3530 & 0.0252 & $14.03^{*}$ & 0.2364 & 0.0481 & $4.91 *$ \\
\hline 3 & 06 and 07 & 0.0345 & 0.0198 & $1.74^{\mathrm{ns}}$ & 0.4439 & 0.0187 & $23.74^{*}$ & 0.3460 & 0.0326 & $10.63^{*}$ \\
\hline 4 & 07 and 08 & 0.1223 & 0.0209 & $5.86^{*}$ & 0.0211 & 0.0130 & $1.63^{\mathrm{ns}}$ & 0.7177 & 0.0313 & $22.93^{*}$ \\
\hline 5 & 08 and 09 & 0.0114 & 0.0197 & $0.58^{\mathrm{ns}}$ & 0.5985 & 0.0216 & $27.68^{*}$ & 0.1793 & 0.0420 & $4.27^{*}$ \\
\hline 6 & 09 and 10 & 0.0899 & 0.0212 & $4.24^{*}$ & 1.4039 & 0.0232 & $60.50^{*}$ & 0.3363 & 0.0441 & $7.63^{*}$ \\
\hline 7 & 10 and 11 & 0.2090 & 0.0267 & $7.82^{*}$ & 4.5676 & 0.0185 & $246.51^{*}$ & 0.0340 & 0.0434 & $0.78^{\text {ns }}$ \\
\hline 8 & 05,06 and 07 & 0.6657 & 0.0213 & $31.22 *$ & 0.6305 & 0.0211 & $29.82^{*}$ & 0.4662 & 0.0407 & $11.47^{*}$ \\
\hline 9 & 07,08 and 09 & 0.1201 & 0.0200 & $6.00^{*}$ & 0.9539 & 0.0185 & $51.43^{*}$ & 0.7333 & 0.0370 & $19.79^{*}$ \\
\hline
\end{tabular}

$\mathrm{QM}^{1}$ - mean square of the difference; $\mathrm{QM}^{2}$ - mean square of the residuals $\mathrm{F}_{\text {calc }}$ - calculated Graybill $\mathrm{F}$ statistic; ${ }^{*}$ - significant $(\alpha \leq 0.05)$, reject $\mathrm{H}_{0}$; $^{\text {ns }}$ - not significant $(\alpha \leq 0.05)$, do not reject $\mathrm{H}_{0} ; \mathrm{C}$ - combination of APUs.

The t-test, used for the validation of the equations adjusted with volume data from APUs managed in previous years, comparing observed and estimated volumes, showed a significant difference $(p<0.05)$ for the six tested cases for these three species. This indicated that it is not adequate to use equations adjusted at other sites, and corroborated the identity test the models.

\section{Conclusions}

The Schumacher-Hall equation is adequate for commercial volume estimation for standing trees in the managed area in the FNT. The Graybill identity test indicated that the use of a single equation to estimate commercial volume is not recommended, when taking into consideration the species together as a group or the principal commercial species separately. Thus, specific equations should be used for each APU.

The use of data from the previous year to develop volumetric equations for the subsequent year was shown to be inadequate for most tested cases, including when the equations are adjusted specifically for each species. One of the alternatives to circumvent this problem would be to conduct the volumetric analysis of trees in the managed UPA itself instead of on the log landing, a procedure that still needs to be authorized by legislation.

\section{Acknowledgments}

The authors thank the Mixed Cooperative of the Tapajos National Forest (Coomflona), for providing the data that formed the base of this study.

\section{Compliance with Ethical Standards}

Funding: Coordenação de Aperfeiçoamento de Pessoal de Nível Superior - Brasil (CAPES) - Finance Code 001.

Conflict of interest: The authors declare no conflict of interest.

Author contribution: Conceptualization: MFS, JRVG; Data curation: MFS, JRVG; Formal analysis: MFS, JRVG, DLC, AFF, KMAG, RSL, AND; Investigation: MFS, JRVG, DLC; Methodology:
MFS, DLC; Supervision: JRVG, AFF; Validation: JRVG, DLC, AFF, KMAG, RSL, AND; Visualization: MFS, JRVG, DLC, AFF, KMAG, RSL, AND; Writing - original draft: MFS, DLC; Writing - review \& editing: JRVG, AFF, KMAG, RSL, AND.

\section{Literature Cited}

Alvares, C.A.; Stape, J.L.; Sentelhas, P.C.; Gonçalves, J.L.M.; Sparovek, G. Koppen's climate classification map for Brazil. Meteorologische Zeitschrift, v.22, n.6, p.711-728, 2013. https:// doi.org/10.1127/0941-2948/2013/0507.

Andrade, V.C.L. Modelos volumétricos de dupla entrada para aplicar em povoamentos florestais brasileiros. Floresta e Ambiente, v.24, e00135415, p.1-10, 2017. https://doi.org/10.1590/21798087.135415.

Barreto, W.F.; Leão, F.M.; Menezes, M.C.; Souza, D.V. Equação de volume para apoio ao manejo comunitário de empreendimento florestal em Anapú, Pará. Pesquisa Florestal Brasileira, v.34, n.80, p.221-329, 2014. https://doi.org/10.4336/2014. pfb.34.80.721.

Barros, P.L.C.; Silva Júnior, A.T. Equação de volume para árvores de uma floresta tropical densa no município de Anapu, Oeste do estado do Pará, Amazônia oriental. Revista de Ciências Agrárias, v.51, p.115-126, 2009. https://cepnor.ufra.edu.br/index.php?jou rnal=ajaes\&page=article\&op=view\&path\%5B\%5D=146\&path\%5 B\%5D=56. 21 Oct. 2019.

Brasil. Resolução Conama no 406, de 02 de fevereiro de 2009. Estabelece parâmetros técnicos a serem adotados na elaboração, apresentação, avaliação técnica e execução de Plano de Manejo Florestal Sustentável-PMFS com fins madeireiros, para florestas nativas e suas formas de sucessão no bioma Amazônia. Diário Oficial da União, v.146, n.26, seção 1, p. 100, 2009. http://www2. $\mathrm{mma} . g o v . b r / p o r t / c o n a m a / l e g i a b r e . c f m$ ?codlegi=597. 22 Mar. 2020.

Campos, J.C.C.; Leite, H.G. Mensuração florestal: Perguntas e respostas. Viçosa: Editora UFV, 2017. 636p.

Colpini, C.; Travagin, D.P.; Soares, T.S.; Silva, V.S.M. Determinação do volume, do fator de forma e da porcentagem de casca de árvores individuais em uma Floresta Ombrófila Aberta na região noroeste do Mato Grosso. Acta Amazonica, v.39, n.1, p.97-104, 2009. https://doi.org/10.1590/S0044-59672009000100010. 
Cysneiros, V.C.; Pelissari, A.L.; Machado, S.A.; Figueiredo Filho, A.; Souza, L. Modelos genéricos e específicos para estimativa do volume comercial em uma floresta sob concessão na Amazônia. Scientia Forestalis, v.45, n.114, p.295-304, 2017. https://doi. org/10.18671/scifor.v45n114.06.

Espírito-Santo, F.D.B.; Shimabukuro, Y.E.; Aragão, L.E.O.C.; Machado, E.L.M. Análise da composição florística e fitossociológica da Floresta Nacional do Tapajós com o apoio geográfico de imagens de satélites. Acta Amazonica, v.35, n.2, p.155-173, 2005. https://doi.org/10.1590/S0044-59672005000200006.

Gama, J.R.V.; Souza, A.L.; Vieira, D.S.; Leite, H.G. Equações de volume para uma floresta ombrófila aberta, município de Codó, estado do Maranhão. Revista Brasileira de Ciências Agrárias, v.12, n.3, p.535-542, 2017. https://doi.org/10.5039/agraria. v12i4a5489.

Gimenez, B.O. Equações volumétricas e o modelo que utiliza o fator de forma médio: um estudo de caso na Amazônia Central. Manaus: Instituto Nacional de Pesquisas da Amazônia, 2013. 61p. Dissertação Mestrado. https://bdtd.inpa.gov.br/handle/ tede/1696. 29 Mar. 2020.

Gimenez, B.O.; Danielli, F.E.; Oliveira, C.K.A.; Santos, J.; Higuchi, N. Equações volumétricas para espécies comerciais madeireiras do sul do estado de Roraima. Scientia Forestalis, v.43, n.106, p.291-301, 2015. https://www.ipef.br/publicacoes/scientia/ leitura.asp?Article=05\&Number=106\&p=s. 20 Mar. 2020.

Gomes, K.M.A.; Ribeiro, R.B.S.; Gama, J.R.V.; Andrade, D.F.C. Eficiência na estimativa volumétrica de madeira na Floresta Nacional do Tapajós. Nativa, v.6, n.2, p.170-176, 2018. https:// doi.org/10.31413/nativa.v6i2.5237.

Graybill, F.A. Theory and application of the linear model. Massachusetts: Ouxburg Press. 1976. 704p.

Gujarati, D.N.; Porter, D.C. Econometria Básica. Porto Alegre: Editora AMGH, 2011. 918p.

Hernandez Filho, P.; Shimabukuro, Y.E.; Lee, D.C.L.; Santos Filho, C.P.; Almeida, R.R. Relatório final do projeto de inventário florestal na Floresta Nacional do Tapajós. São José dos Campos: INPE, 1993. 126p.

Hosokawa, R.T.; Moura, J.B.; Cunha, U.S. Introdução ao manejo e economia de florestas. Curitiba: Editora UFPR, 2013. 164p.

Instituto Brasileiro do Meio Ambiente e dos Recursos Naturais Renováveis - Ibama. Plano de Manejo da Floresta Nacional do Tapajós. Brasília: Ibama, 2004. 580p. https://www.icmbio.gov. br/portal/images/stories/imgs-unidades-coservacao/flona_ tapajoss.pdf. 15 Mar. 2020.

Loures, L.; Carvalho, D.A.; Machado, E.L.M.; Marques, J.J.G.S.M. Florística, estrutura e características do solo de um fragmento de floresta paludosa no sudeste do Brasil. Acta Botanica Brasilica, v.21, n.4, p.885-896, 2007. https://doi.org/10.1590/ S0102-33062007000400013.

Machado, S.A.; Nascimento, R.G.M.; Augustynczik, A.L.D.; Silva, L.C.R.; Figura, M.A.; Pereira, E.M.; Téo, S.J. Comportamento da relação hipsométrica de Araucaria angustifolia no capão da Engenharia Florestal da UFPR. Pesquisa Florestal Brasileira, n.56, p.5-16, 2008. https://pfb.cnpf.embrapa.br/pfb/index. php/pfb/article/view/58. 03 Apr. 2020.
Mendonça, A.R.; Pacheco, G.R.; Vieira, G.C.; Araújo, M.S.; Interamnense, M.T. Identidade de modelos para estimativa do volume de Pinus. Nativa, v.3, n.4, p.281-286, 2015. https://doi. org/10.14583/2318-7670.v03n04a10.

Regazzi, A.J. Teste para verificar a identidade de modelos de regressão e a igualdade de alguns parâmetros num modelo polinomial ortogonal. Revista Ceres, v.40, n.224, p.176195,1993. http://www.ceres.ufv.br/ojs/index.php/ceres/ article/view/2190/226. 11 Apr. 2019.

Regazzi, A.J.; Silva, C.H.O. Teste para verificar a igualdade de parâmetros e a identidade de modelos de regressão não-linear. I. Dados no delineamento inteiramente casualizado. Revista de Matemática e Estatística, v.22, n.3, p.33-45, 2004. https://pdfs.semanticscholar.org/2a67/ fbe7103d94f34a1285424387680a5f0b5a90.pdf. 15 Apr. 2020.

Regazzi, A.J.; Silva, C.H.O. Testes para verificar a igualdade de parâmetros e a identidade de modelos de regressão nãolinear em dados de experimento com delineamento em blocos casualizados. Revista Ceres, v.57, n.3, p.315-320, 2010. https:// doi.org/10.1590/S0034-737X2010000300005.

Ribeiro, R.B.S.; Gama, J.R.V.; Melo, L.O. Seccionamento para cubagem e escolha de equações de volume para a Floresta Nacional do Tapajós. Cerne, v.20, n.4, p.605-612, 2014. https:// doi.org/10.1590/01047760201420041400.

Rodrigues, C.K.; Lopes, E.S.; Figueiredo Filho, A.; Pelissari, A.L. Identidade de modelos hipsométricos e volumétricos de povoamentos de Pinus com diferentes idades submetidos ao desbaste mecanizado. BIOFIX Scientific Journal, v.2, n.1, p.5459, 2017. https://doi.org/10.5380/biofix.v2i1.51947.

Rolim, S.G.; Couto, H.T.Z.; Jesus, R.M.; França, J.T. Modelos volumétricos para a Floresta Nacional do Tapirapé-Aquirí, Serra dos Carajás (PA). Acta Amazonica, v.36, n.1, p.107-114, 2006. https://doi.org/10.1590/S0044-59672006000100013.

Rufini, A.L.; Scolforo, J.R.S.; Oliveira, A.D.; Mello, J.M. Equações volumétricas para o cerrado sensu stricto, em Minas Gerais. Cerne, v.16, n.1, p.1-11, 2010. https://doi.org/10.1590/S010477602010000100001.

Scolforo, J.R.S. Biometria florestal: parte I, modelos de regressão linear e não linear: parte II, modelos para relação hipsométrica, volume, afilamento e peso de matéria seca. Lavras: ESAL/ FAEPE, 2005. 352p.

Silva, J.N.M.; Carvalho, J.O.P.; Lopes, J.C.A.; Carvalho, M.S.P. Equações de volume para a Floresta Nacional do Tapajós. Boletim de Pesquisa Florestal, n.8/9, 50-63, 1984. https://ainfo. cnptia.embrapa.br/digital/bitstream/CNPF-2009-09/5022/1/ jnsilva2.pdf. 20 Feb. 2020.

Soares, C.P.B.; Paula Neto, F. Determinação do tamanho da amostra em um inventário volumétrico e de biomassa de troncos. Revista Ceres, v.44, n.252, p.142-151, 1997. http://www.ceres. ufv.br/ojs/index.php/ceres/article/view/2403. 29 Mar. 2020.

Soares, C.P.B.; Paula Neto, F.; Sousa, A.L. Dendrometria e inventário Florestal. Viçosa: Editora UFV, 2011. 272p.

Souza, J.P.; Araújo, G.M.; Haridasan, M. Influence of soil fertility on the distribution of tree species in a deciduous forest in the Triângulo Mineiro region of Brazil. Plant Ecology, v.191, n.2, p.253-263, 2006. https://doi.org/10.1007/s11258-006-9240-2. 
Thaines, F.; Braz, E.M.; Mattos, P.P.; Thaines, A.A.R. Equações para estimativa de volume de madeira para a região da bacia do Rio Ituxi, Lábrea, AM. Pesquisa Florestal Brasileira, v.30, n.64, p.283-289, 2010. https://doi.org/10.4336/2010. pfb.30.64.283.

Tonini, H.; Borges, R.A. Equação de volume para espécies comerciais em Floresta Ombrófila Densa no sul de Roraima. Pesquisa Florestal Brasileira, v.35, n.82, p.1-8, 2015. https://doi. org/10.4336/2015.pfb.35.82.738.
Valente, M.D.R.; Queiroz, V.T.; Pinheiro, J.G.; Monteiro, L.A.S. Modelo de predição para o volume total de Quaruba (Vochysia inundata Ducke) via análise de fatores e regressão. Árvore, v.35, n.2, p.307317, 2011. https://doi.org/10.1590/S0100-67622011000200015. Vendruscolo, D.G.S.; Silva, R.S.; Souza, H.S.; Chaves, A.G.S.; Motta, A.S. Modelos volumétricos para teca em diferentes espaçamentos em Cáceres, Mato Grosso. Enciclopédia Biosfera, v.10, n.19, p.13331341, 2014. http://www.conhecer.org.br/enciclop/2014b/ AGRARIAS/Modelos\%20volumetricos.pdf. 13 Apr. 2020. 